\title{
IELTSANDO É QUE A GENTE SE ENTENDE
}

\author{
Ana Paula Guimarães e Anabela Almeida Gonçalves
}

A tradição é o vento que a tua passagem levantar. António José Saraiva

\section{Companheiro de viagem}

Imagine uma moeda. Agora, imagine que está a olhar fixamente para uma das faces. Terá, certamente, uma paisagem ou um rosto pequenino de um grande ilustre. Muito bem. Agora, volte-a ao contrário e imagine o que seria a outra face sem ter nada. Não estar escrita. Não estar preenchida. Imediatamente chegaria à conclusão que tinha sido alvo de uma fraude, pois alguém teria colocado uma moeda falsa a transitar. Ou seja, sendo "manca" de uma das faces, isso impediria a sua circulação.

Serve esta pequena metáfora para conferir o tom de abertura à apresentação do nosso grupo, nascido por volta dos anos 70 e dedicado à divulgação da cultura popular. Efectivamente, o nosso Instituto - Instituto de Estudos de Literatura Tradicional (IELT) ${ }^{1}$ - compõe-se de um vasto corpo de investigadores e colaboradores, oriundos de várias áreas do saber para além da literatura (ética ambiental, biologia, sociologia, antropologia, medicina, artes plásticas e dramáticas... ${ }^{2}$ ), empenhados em analisar, recriar e promover a(s) cultura(s) popular(es) quer recolhendo, conservando, valorizando e recriando ${ }^{3}$, quer inter-seccionando a chamada cultura popular com a cultura dita 'consagrada' ${ }^{4}$, mostrando-as não como antagónicas ou paralelas, mas sim como as duas faces de uma mesma moeda. Se uma das faces faltasse, essa moeda deixaria de ter valor e apagar-se-ia, simples e numismaticamente, da história. Deste modo, muito do nosso trabalho reverte a favor de uma certa mediação, no sentido de nos empenharmos na produção de estudos e outros materiais, frutificados a partir do esforço e dedicação dos que se interessam por estas questões do foro popular/tradicional/oral e adubada pela convicção de que é um dever nosso, perante tão importante legado com que o tempo se encarregou de nos presentear, mantê-lo vivo através do sopro da divulgação e tratamento teórico e prático.

Estribados na epígrafe de António José Saraiva, também nós pensamos que a tradição não é estática nem imutável (ao contrário do lugar comum "a tradição já não é o que era", dizemos que "a tradição nunca foi o que era"), mas um reduto de seiva que nos compete estimular e alimentar, recuperando-a do passado e 'instalando-a' no presente como passaporte para um futuro antecipadamente vivido nesta necessária recuperação e re-vivência da tradição. Por tudo isso, as linhas de orientação e actuação do nosso Instituto passam pela dinamização destas culturas também chamadas populares, enquanto trabalhamos com o entusiasmo que a reflexão sobre as tradições pode desencadear entre quem se queira debruçar mais atentamente sobre ela e sobre seus pares. Encorajando, assim, o respeito a ter relativamente à sua especificidade bem como recriando em formas inéditas aquilo que era considerado desgastado, moribundo ou mesmo morto, entusiasmando para o ensino desta vasta e prenhe área de estudos em níveis escolar e universitário, enfatizando a promoção local, regional e geral dos conhecimentos.

Sublinhando, portanto, os nossos objectivos, podemos dizer que os mesmos são, por um lado, reconhecer a literatura tradicional/oral/popular enquanto parte do património imaterial e universal da

\footnotetext{
As IELTsistas

${ }^{1}$ Classificado de "Excelente" na avaliação levada a cabo pela FCT - Fundação para a Ciência e a Tecnologia.

${ }^{2}$ É esta diversidade de disciplinas que nos permite desenvolver variados projectos tais como: Projecto "Falas da Terra", "Os Respigadores e a Respigadora" (Agnès Varda), "Medicina Popular"...

${ }^{3}$ Projecto "Cantos, contos... e que mais".

${ }^{4}$ Projecto "Tradição e Modernidade".
} 
humanidade, veículo de afirmação por excelência da identidade e de aproximação entre os povos (Unesco), pensando, desta forma, o lugar ocupado pela literatura tradicional e a(s) cultura(s) popular(es) relativamente às sociedades, culturas e literaturas contemporâneas, redefinindo-as dentro do perfil de investigação académica.

Por outro lado, e reportando-nos a um aspecto mais prático, pretendemos recolher e analisar materiais de diversos géneros literários (cancioneiros, romanceiros, contos, anedotas, lendas, adivinhas e outros textos), de diversas culturas e sociedades, solicitando a convergência de diversas disciplinas (etnologia, antropologia, sociologia, ciências ambientais, por exemplo), no sentido de prosseguir estudos inter e transdisciplinares, visando a uma compreensão abrangente do mundo literário, cultural e social.

Para além disso, outra das nossas metas é continuar a desenvolver projectos de investigação e divulgação de recolhas e produções artísticas (documentários cinematográficos, exposições, espectáculos, edição de CDs, DVDs) relacionados com a cultura oral/popular/tradicional, incentivando o reconhecimento do valor dessas manifestações na sociedade e arte contemporâneas. Paralelamente, tencionamos continuar a dinamizar acções de apresentação e valorização de patrimónios de culturas populares, em comunidades rurais e/ou urbanas, quer conservando quer inovando sobre práticas porventura ancestrais.

Deste nosso grupo fazem também parte exímios contadores de histórias (alguns vestidos a rigor e tudo!) e inúmeros especialistas nessas questões, dispostos a levar cada vez mais longe o entusiasmo pela tradição que os move e promove a sua dedicação, cheios de ideias... para milhares de actividades que se podem fazer nesse âmbito e que, devido ao seu carácter envolvente e abrangente, são capazes de cativar um vasto e eclético público.

Para além disso, e em consonância com outras actividades, o nosso Instituto ocupa-se da distribuição do portfolio "Gigantones \& Companhia" (editado em português, espanhol e inglês), que visa a estimular a criatividade dos menores e dos maiores, começando por os envolver com personagens das tradicionais festas de Viana do Castelo, fora do contexto da festa, transportando-os para um mundo tão quotidiano quanto fantástico e naturalmente educativo. O portfolio é constituído por uma selecção de fotografias da autoria de Virgílio Ferreira, destinadas a desencadear os objectivos criativos dessa nossa iniciativa, promovendo muitos outros projectos de maiores ou menores dimensões. Espreite o nosso "GrandePequeno", isto é, o nosso pequeno trabalho sobre o nosso grande respeito pela diferença, consultando o site <www.grandepequeno.com $>$.

Se quiser mergulhar no nosso mundo e conhecer-nos melhor - pois é a IELTsar que a gente se entende - , sugerimos que visite o nosso recanto na aldeia global: <www.ielt.org $>$, o qual esperamos que se torne num ponto de encontro entre nós e vós, filhos de países irmãos ou primos, todos decerto da mesma família. Por isso mesmo ficamos à espera de uma palavra sua. Para nos ajudar a polir a outra face da moeda. 